\title{
Factors Influencing Accounting Outsourcing Practices among SMEs in Pakistan Context: Transaction Cost Economics (TCE) and Resource-Based Views (RBV) Prospective
}

\author{
Ajmal Hafeez ${ }^{1} \&$ Otto Andersen ${ }^{1}$ \\ ${ }^{1}$ Faculty of Economics and Social Sciences, University of Agder, Norway \\ Correspondence: Ajmal Hafeez, Faculty of Economics and Social Sciences, University of Agder, Norway. \\ E-mail: luckyajmal786@hotmail.com
}

Received: April 10, 2014

Accepted: May 15, 2014

Online Published: June 22, 2014

doi:10.5539/ijbm.v9n7p19

URL: http://dx.doi.org/10.5539/ijbm.v9n7p19

\begin{abstract}
The present study was conducted to identify factors that affect Pakistani manufacturing SMEs decisions to outsource management accounting practices in terms of transaction cost economics (TCE) and resource-based view (RBV). A survey of 302 SMEs was carried out using convenience sampling, a personal interview owners/managers/CFOs located in 9 major cities of Pakistan. Our multiple regression analysis revealed that the frequency of non-routine tasks, asset specificity, opportunism, trust in accountant and competition has a significant impact on accounting outsourcing. Furthermore, whilst we include control variables like gender, executive education, experience, firm size and firm age in our linear regression equation, the relationship among five variables and outsourcing intensity was remain statistically significant. The findings imply that SMEs with resource constraint should shift their traditional in-house accounting practices to the external knowledgeable professional accountant. Finally, this study contributes to the body of knowledge with respect to management accounting outsourcing, TCE and RBV in the emerging economics context.
\end{abstract}

Keywords: SMEs, Accounting functions, professional accountant, outsourcing, transaction cost economics (TCE), resource based view (RBV)

\section{Introduction}

Small and Medium-Sized enterprises (SMEs) add considerably to economic development in term of job creation, gross domestic product (GDP) and help to stabilize the national economy in emerging countries (Ale-Ebrahim et al., 2010). Conversely, SMEs in emerging economics deal with increasing complexities and fail to perform due to internal resource gap (Kamyabi \& Devi, 2011c). Moreover, smaller firms are less efficient than larger firms in resource allocation and utilization (Gooderham et al., 2004). Therefore, accounting information is particularly essential for SMEs better resource management (Nandan, 2010), reduce cost and create new opening for business growth (Mahmoodzadeh et al., 2009). In addition, outsourcing improves internal quality through expert knowledge of the available external resources (Jiang \& Qureshi, 2006). Despite the importance of accounting information for the SMEs sector, "accounting outsourcing research still remains a neglected and an unfashionable area" (Kamyabi \& Devi, 2011e, p. 1696).

The business environment in the world has become volatile and unpredictable as a result of economic globalization, market maturity, increasing customer demands, rapid technological change and fierce competition (Kamyabi \& Devi, 2011a). Therefore, business management has become more challenging and complicated (Lamminmaki, 2007; Espino-Rodríguez \& Padrón-Robaina, 2004). In a such business environment Small and Medium size Enterprises (SMEs) are vulnerable and face significant challenges as a consequence of internal resource constraints (Kamyabi \& Devi, 2011c). To overcome such difficulties, the practitioner recommended that SMEs outsource their tasks by shifting what they traditionally managed internally (Lamminmaki, 2008; Kotabe $\&$ Mol, 2009) and in particular, their accounting functions (Kamyabi \& Devi, 2011b). Hence, the outsourcing of accounting activities is an opportunity for SMEs to stay competitive in the competitive business environment (Jayabalan et al., 2009; Everaert et al., 2010). SMEs generally lack the required resources, skills and expertise to execute accounting practices internally (Kamyabi \& Devi, 2011a), the realization of access to knowledge and skills of the external accountant was the main rationale to consider outsourcing choice (Everaert et al., 2007). 
External accountants are in a unique position to advise the management of SMEs, to achieve business objectives in the long term and improve sustainability (Martin, 2005; Ismail and King, 2005; Samujh and Devi, 2010).

Previous studies confirm that SMEs involved in the outsource of management accounting functions to professional accountants in recent years (Kamyabi \& Devi, 2011; Everaert et al., 2010, 2007; Jayabalan et al., 2009; Carey et al., 2006; Gooderham et al., 2004). Moreover, most research has been conducted in developed countries. Therefore, the researcher suggested that there is a need for further validation of accounting outsourcing practices in small firms, particularly for emerging economics like Pakistan (Kamyabi \& Devi, 2011; Mashayekhi \& Mashayekh, 2008; Everaert et al., 2010). A number of researchers have also identified that accounting outsourcing practices in SMEs have not received considerable attention and still remain neglected as comprehensive investigation of management accounting research by applying a combination of TCE and RBV prospective (Kamyabi \& Devi, 2011; Brandau \& Hoffjan, 2010).

Therefore, the proposed study will explore SMEs intensity to outsource management accounting tasks draws on both TCE and RBV prospective. In this context, the association between outsourcing intensity and five independent variables such as frequency of non-routine tasks, asset specificity, opportunism, trust in accountant and competition are examined. This study extends the Kamyabi \& Devi (2011) conducted in developing economy, Iran and Everaert et al., (2010) conducted in a developed European economy, Belgium, in three ways. Firstly, this study included two additional variables, frequency of non-routine tasks and opportunism derived from the TCE prospective that is relevant in an emerging economy context. Previous researchers disregard the role of opportunism in management accounting outsourcing in TCE prospective. Secondly, it is empirically argued that most studies on outsourcing have been conducted in developed economies and one can wonder if such evidence is relevant to emerging economics like Pakistan (Mashayekhi \& Mashayekh, 2008) because of difference in an institutional framework (Devi \& Samujh, 2010), the intensity of government interference in the economic regulations (Ismail \& Zin, 2009). Finally, Everaert et al. (2010) consider these variables (i.e., frequency, asset specificity and trust in accountant) with regard to outsourcing of financial accounting tasks like bookkeeping, period ends accounting and preparation of financial statements based on TCE model. This study emphasizes on the outsourcing of management accounting functions, rather than outsourcing of financial accounting tasks. Taken as a whole, this study identifies factors affecting Pakistani SMEs outsourcing intensity by applying a combination of TCE and RBV prospective in emerging economics context.

The rest of the discussion is organized as follows: Section 2 provides the background of the study. Moreover, section 3 reviews the literature and develops hypotheses using TCA and RBV prospective to guide the framework to investigate management accounting outsourcing practices. Furthermore, section 4 discusses the research methodology. In addition, section 5 presents the findings and discussion on the results implication. Finally, section 6 concludes and give suggestions.

\section{Background of Study}

\subsection{An Overview of the Pakistani Economy}

Pakistan has a population of 184.35 million and the majority of these people are young people (Wasti, 2013). The Pakistani economy is largely depending on a commodity sector comprises of agriculture and industry; contributed 42.3 percent of GDP in year 2012-2013 (Wasti, 2013). The agriculture sector is a major source of raw material to industrial unit accounts for 21.4 percent of the GDP, which employs 45 percent labor force and contribute 60 percent in exports (Farooq, 2013). However, agriculture and industry move by, hand in hand in Pakistani economy. Moreover, the country face very challenging and unstable economic situation, the real growth rate in 2012-13 is 3.6 percent as compared to 9.0 percent was in 2004-05; inflation rate over 7.5 percent and unemployment rate is 6 percent (Wasti, 2013). Hence, the most challenging situations for Pakistani economy is to generate employment opportunities for people who are willing to work. These economic indicators can be achieved by recognizing the significance of small businesses that generate employment and development of the nation (Khalique et al., 2011).

\subsection{Small and Medium Enterprises (SMEs) in Pakistan}

The Small and Medium Enterprises Development Authority (SMEDA) is an institution in Pakistan working under the ministry of industries was established in 1998 to facilitate and regulate SMEs in enhancing their capabilities and competitiveness. According to the SMEDA definition of SMEs are divided into three classes, for example, (a) employment size up to 250, (b) paid up capital up to Rs. 25 million and (c) annual sales up to Rs. 250 million (Khalique et al., 2011). Moreover, Pakistani SMEs constitute 90 percent of all the enterprises; 80 percent of the non-agriculture manpower employed by SMEs and contribute estimated 40 percent in the annual GDP of the country (Khalique et al., 2011). 


\subsection{Professional Accountants and Financial Reporting in Pakistan}

After independence in 1947, Pakistan implemented the British accounting rules such as the Companies Act 1913 and Audit rules 1932 (Saeed, 1993). Later, in 1961, The Institute of Chartered Accountants of Pakistan (ICAP) was established under the Accountant Ordinance in 1961, as an independent professional body with the objective to regulate the accounting and auditing functions in Pakistan (Badshah, 2013). In 1966, the Institute of Cost and Management Accountants of Pakistan (ICMAP) was established in order to regulate the management accounting profession. In 1997, the formation of Securities and Exchange Commission of Pakistan (SECP) is a major development to improve regulations concerning financial reporting, auditing, superintendence and control of corporate entities in Pakistan, and work closely with ICAP (ICAP, 2007). Therefore, laws require that auditors should be member of ICAP to audit every listed firm, pubic joint stock firms and other legal business entities are required auditing and present their financial reports (Rashid et al., 2012). Pakistan was planning to adopt International Financial Reporting Standards (IFRS) for SMEs through ICAP, for example "medium sized enterprises must follow the accounting and financial reporting framework and standard for medium-sized entities" (ICAP, 2007, p. 12). In fact, ICAP (http://www.icap.org.pk) plays an important role in the Pakistani SMEs environment through professional accountants.

\subsection{Outsourcing of Accounting Functions in SMEs}

The concept of outsourcing was first introduced in the last period of 1980 (Hussey and Jenster, 2003). Outsourcing refers as an external service supplier to a firm (Carey et al., 2006). However, the management accounting outsourcing is a practice involves 'external accountant' both external professional accountant and accounting firm (Kamyabi \& Devi, 2011; Everaert et al., 2010). For example, in Pakistan, SMEs can get services from an external professional accountant, both an individual accountant and accounting firm with valid ICAP certificates. In Pakistan external accountant are providing accounting services (costing, financial statement, etc.), advisory services and auditing services (e.g., financial audit and tax audit etc.) (ICAP, 2013). Thus, many previous studies confirm that SMEs prefers to outsource their accounting functions to an external professional accountant. In Belgium over two-third firms outsource accounting functions (Everaert et al., 2010), in Australia and UK majority of firms outsource accounting tasks (Carey et al., 2006), in Norway many firms are involved in outsourcing of accounting services support (Gooderham et al., 2004). However, in the previous literature, most of the studies on accounting outsourcing were done in the developed countries except from Malaysia by Jayabalan et al. (2009) and latest in Iran by Kamyabi and Devi (2011). Therefore, there is a need to explore more SMEs accounting outsourcing functions in emerging economics such as Pakistan.

\section{Theoretical Framework and Hypothesis}

Transaction cost economics (TCE) theory has developed into a useful framework to explain why several SMEs performs management accounting tasks in-house, while other firms approach professional accountant who can help them to minimize transaction cost (Kamyabi \& Devi, 2011; Everaert et al., 2010; Klein, 2005; Carey et al., 2006). The decision to outsource or internalize depends on the comparative transaction cost to avail that service such as the ex-ante negotiation cost and the ex-post performance and feedback (Williamson, 1985). TCE describes frequency, asset specificity and trust in accountant are essential components influencing accounting outsourcing decision (Everaert et al., 2010; Lammirmiaki, 2005; Spekle et al., 2007). Resource based view (RBV) theory has happened to a practical framework to describe why SMEs use external accountant services under competitive pressure (Gooderham et al., 2004). The transaction cost economics (TCE) primarily focus on governance (Mclvor, 2009). Whereas, RBV primarily focuses on production of capabilities and skills to achieve competitive benefit and performance (Barney, 1991; Gottschalk \& Solli-Sœther, 2006; Mclvor, 2009; Kamyabi \& Devi, 2011c). Therefore, the RBV describes that the level of competition becomes a major influencing factor affecting the decision of outsourcing accounting functions (Gooderham et al., 2004; Kamyabi \& Devi, 2011c; Kamyabi \& Devi, 2011d). Based on the arguments, TCE and RBV are complementary for outsourcing choice (McNally \& Griffm, 2004; Kamyabi \& Devi, 2011c; Gottschalk \& Solli-Saether, 2006; Poppo \& Zenger, 1998; Mclvor, 2009; Espino-Rodríguez et al., 2008). However, we provide some empirical evidence concerning SMEs outsources of accounting activities to professional accountant as given below one by one.

\subsection{Frequency}

Transaction frequency means the frequent or recurrent of the similar transaction (Murrey, 2001; Lamminmaki, 2007). Frequent or recurring activities can generate advantage of economies of scale (Widener \& Selto, 1999) that allow the recovery of setup costs (Everaert et al., 2010). Consequently, TCE anticipated that frequent or recurrent activities are apparently to be produced internally (Williamson, 1985; Everaert et al., 2010). The frequency of accounting tasks can be classified as 1) periodicity of the accounting task and 2) the size of tasks 
(Everaert et al., 2010). First, periodicity of accounting tasks in particular describes as each of the accounting functions can be processed daily, weekly, monthly, quarterly, semi-yearly and yearly (Everaert et al., 2010). However, there are certain laws on accounting exist when it comes to the preparation of financial statements, for example, once a year; various business concerns prepare financial statements many times (Everaert et al., 2010). Secondly, the frequency can be understood by the size of the business activity (Everaert et al., 2010). Such as, a company processing the 20 invoices each month has a lower frequency of invoice entry than a company that deal with 2000 invoices each month. Therefore, an old company (20 invoices) is more attractive to outsource accounting function than the later one (Everaert et al., 2010). The frequency for accounting is categories into two tasks (Murray \& Kotabe, 1999). A. Routine accounting tasks (entry of financial invoices, interim reporting) and B. non-routine accounting tasks (period end accounting and preparation of financial statements). According to Williamson, (1985, p. 60) high frequency trading will lead to the choice of hierarchical governance means that the internalization-the company chooses to produce the product or service, instead of buying it from a supplier. Consequently, the following hypothesis is suggested:

Hypothesis 1: The higher the frequency of accounting non-routine tasks the less intensively accounting functions are outsourced.

\subsection{Asset Specificity}

TCE and RBV predict that asset specificity is one of the demanding factors affecting the outsourcing intensity (Mclvor, 2009; Reeves et al., 2010; Kamyabi \& Devi, 2011). Two common categories of specific assets, called tangible assets (i.e. land, machinery and equipment) and intangible assets (e.g., skills, ability, knowledge) (Barney, 1991; Lamminmaki, 2005; Mclvor, 2009). For instance, in the accounting perspective, tangible assets identify such as accounting software and intangible asset specify to human capital (e.g., information, competence and knowledge), that can be accessed from the market. Indeed, human assets are specific when professional accountants entail specialized knowledge of the particular attribute of a business concern (Everaert et al., 2010) while to perform a special accounting function. In accordance with TCE, when transactions are somewhat recurrent and asset specificity is low, such transactions are most likely to be governed by outsourcing (Chang et al., 2009; Jiang et al., 2007; Watjatrakul, 2005). TCE argues that once the accounting tasks entail high intensity of asset specificity, the search for external accountant will be extensive (Nicholson et al., 2006) and contractual negotiations are more argumentative (Espino-Rodríguez et al., 2008). Furthermore, accounting activities turn into more tailored to a firm, asset specificity increases and correspondingly, transferring accounting functions to a professional accountant can be problematic and expensive (Everaert et al., 2010; Nicholson et al., 2006). However, Everaert et al. (2010) found that there is a significant association between accounting outsourcing and asset specificity. Therefore, TCA and RBV literature argue that asset specificity is an influencing factor in outsourcing decisions (Everaert et al., 2010; Kamyabi \& Devi, 2011; Watjatrakul, 2005). Thus, the proposed hypothesis states:

Hypothesis 2: The higher the level of asset specificity of accounting functions, the lower the intensity of outsourcing of accounting functions.

\subsection{Opportunism}

The term opportunism is defined as "self-interest seeking with guile" (Williamson, 1985, p. 47), has established considerable attention from marketing researchers because it disrupts business results in exchange relationships as a result of "propensities to disseminate, distort, fail to disclose, and otherwise act in an untrustworthy and even fraudulent manner for purposes of the translator's own gain" Wang (2002). Opportunism can appear 'before the firms transact' or 'after the transaction is underway', well-known as ex ante and ex post opportunism, respectively (Jap \& Anderson 2003, p. 1686). Whereas ex ante opportunism can be viewed and controlled comparably easily and safely, the ex post opportunism is less feasible to be seen or controlled before it occurs (Lai et al., 2012). Although opportunism is widespread in number of relationship exchanges and has been broadly investigated in the literature related to the transaction cost, there are few empirical studies that deal with opportunism, especially ex post opportunism (Jap \& Anderson, 2003), and its safeguards in accounting outsourcing relationships. TCE theory postulates there is a positive association between the level of dependence of an exchange partner (e.g., a buyer) and the tendency of their partner (e.g., a supplier) will act opportunistically (Hawkins et al., 2009). Opportunism in accounting outsourcing can certainly mean one party (service provider) increase cost or decrease revenue for the injured party (service receiver) (Wathne \& Heide, 2000). In addition, the opportunistic behavior of service provider decrease trust, commitment, cooperation, satisfaction and specially damage the long run relationship between individual firm and service provider (Kwon \& Suh, 2005; Lee, 1998; Joshi \& Stump, 1999). According to Everaert et al. (2010) an external accountant has developed such a 
relationship with the manager or owner that carry on commitment, take action, act predictable manner and minimize opportunism. Hence, the opportunistic behavior of service provider has a big influence economic decision and the complementary factor in the governance of exchange relationships in TCE prospective. Consequently, based on the discussion above, the hypothesis is proposed as follows:

Hypothesis 3: The stronger the perception that the external accountant will behave opportunistically, the less intensely the accounting functions are outsourced.

\subsection{Trust in Professional Accountant}

The trust can be defined as the expectation of SMEs executive that the professional accountant (Kamyabi \& Devi, 2011a) can be trusted upon to carry out legal obligations, possess knowledge and expertise (Lamminmaki, 2007), will act in a predictable way (Espino-Rodríguez et al., 2004.), will charge fairly for accounting service provided and will act and negotiate honestly, when the likelihood of opportunism exists (Everaert et al., 2010). Many studies show that the relationship between an external service provider and outsourcing should be analyzed based on TCE prospective (Brouthers, 2003; Everaert et al., 2010; Greenberg et al., 2008; Kamyabi \& Devi, 2011). TCE argues that trust between the firm and external service providers enhance their relationship, the cost of transactions and potential threat of opportunism will be minimized (Greenberg et al., 2008; Tian et al., 2008; Verwaal et al., 2008). Consequently, TCE supports the perspective that while trust exists, the formal structure of command can be restricted and company likely to outsource business activities (Verwaal et al., 2008; Lee et al., 2008). All in all, higher the level of anticipated trust in external accountants, the greater is the tendency that SMEs executive will prefer to outsource management accounting tasks (Lee et al., 2008; Everaert et al., 2010; Verwaal et al., 2008; Greenberg et al., 2008). Consequently, the suggested hypothesis is as follows:

Hypothesis 4: The higher the level of trust of the SME owner/manager in the external accountant, the more intensely the accounting functions are outsourced.

\subsection{Degree of Competition}

Resource based view (RBV) explained a number of dimensions that cause smaller firms more vulnerable than larger firms as a consequence of competitive pressure and their internal resource gaps (Kamyabi \& Devi, 2011b; Gooderham et al., 2004; Espino Rodríguez et al., 2004). Consequently, many companies have expanded the scope of outsourcing to exploit the available resource outside the company to assist their businesses to become more competitive and the pressure to stay lean (Worrall, 2007; Gooderham et al., 2004). For example, in this context, the outsourcing of accounting functions is the method of choice for small businesses to survive and stay lean in the competitive market (Lamminmaki, 2007; Gooderham et al., 2004). TCE show firms to select proper governance structure type like outsourcing to reduce transaction cost (Kamyabi \& Devi, 2011; Greenberg et al., 2008; Nicholson et al., 2006). For instance, many claim that in the competitive environment, the association between outsourcing and internal resource gaps is critical to consider (Kamyabi \& Devi, 2011; Espino \& Robaina, 2005; Gooderham et al., 2004; Espino Rodríguez et al., 2004). Therefore, in such a competitive pressure situation firms with small size are required to outsource external services for firm future growth and development (Gooderham et al., 2004). Furthermore, the competitive pressure intensity forced SMEs rely on external accountants to cut costs for achieving sustainable competitive advantages (Delmotte \& Sels, 2008; Jiang \& Qureshi, 2006). Accordingly, based on the discussion above, the hypothesis is proposed as follows:

Hypothesis 5: The stronger the competitive pressures faced by the company, the more likely it is that management accounting functions will be outsourced.

\section{Research Methods}

\subsection{Data Collection}

Based on the definition of SMEs in the Pakistani context Khalique et al. (2011), we limit our survey population to companies in terms of number of employees in the range of less than 250 employees. We utilized the Pakistani Small and Medium Enterprises Development Authority (SMED A database (http://www.smeda.org), not including services sector and included only manufacturing sector. An outsourcing questionnaire survey was carried out in 9 cities of Punjab Province in Pakistan. The responses were collected on the basis of face to face interaction and interviews with SMEs owners/managers/CFOs. Throughout the research 500 SMEs owners/managers/CFOs were contacted by personal visit to each company office as well as approach SMEs owners/managers via local chamber of commerce. As the total sample size for this research was decided to be approximate 350, around 25 to 70 completely filled questionnaires each of the 9 different locations were used for analysis. The main reason to get the questionnaires filled face to face was that personal contact encourage and motivates the SMEs owners/managers/CFOs to give more accurate data and also verbal communication in native 
language takes less time to get the questionnaire completed. Respondents were clearly informed and explained that they are participating in a study for a Master's Thesis research. Finally, we had only 302 usable responses, representing a very effective response rate of 73 percent.

\subsection{Variable Measurements}

The dependent and independent variables were measured and evaluated on a seven point Likert-type scale and found adequately high Cronbach's alpha for all variables (above 60\%). The details are presented in Table 1.

Table 1. Multi-item variable measurement

\begin{tabular}{|c|c|c|c|}
\hline Variables & Items & Source & $\begin{array}{l}\text { Cronbach's } \\
\text { alpha }\end{array}$ \\
\hline $\begin{array}{l}\text { Outsourcing } \\
\text { intensity }\end{array}$ & $\begin{array}{l}\text { 1. Interim reporting } \\
\text { 2.Period-end accounting } \\
\text { 3.Preparation of financial statements } \\
\text { 4.Management accounting } \\
\text { 5.Business advice } \\
\text { 6.Management consultancy } \\
\end{array}$ & $\begin{array}{l}\text { Espino-Rodríguez et al. } \\
\text { (2008); Kamyabi \& Devi, (2011) }\end{array}$ & 0.80 \\
\hline Frequency & $\begin{array}{l}\text { 1.Period end accounting ( } 1 \text { daily; } 6 \text { annually)* } \\
\text { 2.Preparation of financial statements ( } 1 \text { daily; } 6 \\
\text { annually)* }\end{array}$ & Everaert et al. (2010) & 0.67 \\
\hline Asset specificity & $\begin{array}{l}\text { 1. To perform the non-routine accounting tasks the } \\
\text { accountant needs to acquire company-specific information } \\
\text { 2. The way we perform the accounting tasks are unique to } \\
\text { our company } \\
\text { 3. It would be costly in terms of time and resources to } \\
\text { switch to an external accountant at the end of the financial } \\
\text { year. }\end{array}$ & $\begin{array}{l}\text { Everaert et al. (2010); Kamyabi } \\
\text { \& Devi (2011) }\end{array}$ & 0.68 \\
\hline Opportunism & $\begin{array}{l}\text { 1. Sometime external accountant alters the facts slightly in } \\
\text { order to get what they need. } \\
\text { 2. Sometime external accountant lies about certain things } \\
\text { in order to protect their interest. } \\
\text { 3. Sometime external accountant promises to do things } \\
\text { without actually doing them later } \\
\text { 4. Sometime external accountant does not fulfil } \\
\text { obligations in accordance with our contract. } \\
\text { 5. Sometime external accountant tries to deceive us. }\end{array}$ & New Measures & 0.82 \\
\hline Trust in accountant & $\begin{array}{l}\text { 1. The owner/manager has confidence that the external } \\
\text { accountant will inform correctly } \\
\text { 2. The owner/manager feels that external accountant care } \\
\text { about what happens to us. } \\
\text { 3. The relationship between the owner-manager and the } \\
\text { external accountant is based on trust. }\end{array}$ & $\begin{array}{l}\text { Everaert et al. (2010); One New } \\
\text { Measure }\end{array}$ & 0.81 \\
\hline Competition & $\begin{array}{l}\text { 1. Product characteristics } \\
\text { 2. Promotional strategies among rivals } \\
\text { 3. Access to distribution channels }\end{array}$ & $\begin{array}{l}\text { Rivard et al. (2006); } \\
\text { lamminmaki (2008); Kamyabi \& } \\
\text { Devi (2011) }\end{array}$ & 0.65 \\
\hline
\end{tabular}

Note. * reverse coding.

\subsubsection{Dependent Variable: Outsourcing Intensity}

In order to realize the aim of this study, we consider the six types of management accounting functions with the assumption (based on Kamyabi \& Devi, 2011) that these functions are applicable and frequently performed by the accountants in Pakistan. Therefore, in order to measures the accounting outsourcing functions, we used the measurement developed by (Kamyabi \& Devi, 2011) on a 7 point Likert type scale, asking respondents to indicate the level of management accounting functions outsourcing of each item with $1=$ not outsourcing to $7=$ totally outsourced. 
Table 2. Demographic profile of respondents

\begin{tabular}{|c|c|c|c|}
\hline Variable & Item & $\mathrm{N}$ & Percentage $(\%)$ \\
\hline \multirow[t]{2}{*}{ Gender } & Male & 237 & 78.5 \\
\hline & Female & 65 & 21.5 \\
\hline \multirow[t]{2}{*}{ Education } & University Degree & 242 & 80.1 \\
\hline & Lower than University Degree & 61 & 18.9 \\
\hline \multirow[t]{5}{*}{ Experience } & Less than 5 years & 168 & 55.6 \\
\hline & $5-10$ years & 67 & 22.2 \\
\hline & $11-15$ years & 38 & 12.6 \\
\hline & $16-20$ years & 11 & 3.6 \\
\hline & More than 20 & 17 & 5.6 \\
\hline \multirow[t]{8}{*}{ Firm Size } & Less than 20 employees & 53 & 17.5 \\
\hline & 20-30 employees & 29 & 9.6 \\
\hline & $31-50$ employees & 36 & 11.9 \\
\hline & 51-100 employees & 27 & 8.9 \\
\hline & 101-150 employees & 62 & 20.5 \\
\hline & 151-200 employees & 48 & 15.9 \\
\hline & 201-250 employees & 47 & 15.6 \\
\hline & More than 250 & - & - \\
\hline \multirow[t]{6}{*}{ Firm Age } & Less than 2 years & 17 & 5.6 \\
\hline & $2-5$ years & 102 & 33.8 \\
\hline & $6-10$ years & 44 & 14.6 \\
\hline & $11-15$ years & 24 & 7.9 \\
\hline & $16-20$ years & 72 & 23.8 \\
\hline & More than 20 & 42 & 13.9 \\
\hline
\end{tabular}

\subsubsection{Independent Variables}

Frequency is defined in this study as by combining a periodicity measure (daily, weekly, monthly, quarterly, semi-annually and annually) with a volume measure (transactions, number of invoices etc.) similar to Everaert et al., (2010). Frequency of non-routine tasks in management accounting outsourcing means the frequent or recurrent of accounting transaction (Murrey, 2001). Therefore, in order to measures the frequency, we adopted the measurement use by Everaert et al., (2010) on a 6 point Likert type scale, asking respondents to indicate the frequency to what extent periodicity and volume related non-routine workload is being outsourced of each item with $1=$ daily to $6=$ annually.

Asset specificity measure primarily refers to human asset specificity which accountants need such as specialized knowledge (Everaert et al., 2010) to perform particular accounting tasks. Thus, in order to measure the asset specificity, we used measures previously tested and validated by (Everaert et al., 2010; Poppo \& Zenger, 1998) to ask respondents on a 7 Likert scale $1=$ totally disagree to $7=$ totally agree, whether the accountant need to acquire firm specific information in order to adequately perform the management accounting practices.

The opportunistic behavior of service provider decrease trust, commitment, cooperation, satisfaction and specially damage the long run relationship between individual firm and service provider (Kwon \& Suh, 2005; Lee, 1998; Joshi \& Stump, 1999). Therefore, to measure opportunism in accounting outsourcing services, the respondents will be asked at what extent they perceived the external accountant opportunistic behavior on a 7 Likert scale $1=$ totally disagree to $7=$ totally agree.

Trust in accountant was measured based on earlier studies (Kamyabi \& Devi., 2011; Everaert et al., 2010), by asking respondents to indicate the extent to which they trust the professional accountant with each of statement on a 7-point Likert scale with the range from 1-totally disagree to 7-totally agree.

For measuring competition, we drew items from prior studies (Kamyabi \& Devi, 2011; Rivard et al., 2006), asking respondents to indicate the intensity of their firm competition for each item on a 7 point Likert type scale with $1=$ very weak competition to $7=$ very fierce competition.

Nevertheless, a factor analysis of the relevant items did requires measurement changes. These included the removal of 2 items from measurement of asset specificity, 2 items from measurement of trust in accountant, and 2 items from degree of competition in order to achieve the required factor structure and satisfactory internal 
reliability levels.

\subsubsection{Control Variables}

RBV describes the use of external services interrelates with the size and age of the company (Bennett \& Robson, 2003). Empirical studies indicated that the use of external advisory services by SMEs is significantly positively related to the size and age of the firm (Dyer \& Ross, 2008; Bennett \& Robson, 1999). Accordingly, we used the firm age and firm size as control variables alike as Gooderham et al. (2004), the respondents will be asked total number of people employed in the company. In addition, the respondents will be asked at what year your firm was registered alike to Mole et al. (2008). Furthermore, prior studies found that the SMEs executive educational background has been linked to the level of firm outsourcing of external services (Park \& Krishnan, 2001; Everaert et al., 2010). Consequently, to measure SMEs executive educational background, the respondents will be asked to indicate their highest level of education similar to Everaert et al. (2010). We also include the gender of SMEs executives as a control variable to see the association with external accounting service. Finally, according to Audet and St John (2007) the use of external advisory services are negatively associated with the SMEs executive experience. We drew the extent developed by Audet and St John (2007), asking respondents how long they have worked in the business.

\section{Results}

\subsection{Respondent Characteristics}

The respondents of the study included 78.5 percent male and 21.5 percent female. Most of the respondents were quite well educated (80.1 percent) and the common level of managerial experience was high with nearly half of respondents having over five years of experience. In addition, Table 3 shows the means and standard deviation (S.D) and correlations among the independent variables. The correlation between independent variables was such that multicollinearity is not a concern.

\subsection{Hypotheses Testing}

\subsubsection{Testing for Direct Effects}

A multiple regression analysis is carried out for identifying factors impacting the choice of management accounting outsourcing. We primarily come up with two models in Table 4. In model one, we included the independent variables and the dependent variable in the multiple linear regression. Consequently, the outcome (Model 1) explain a significant positive coefficient 0.123 for frequency of non-routine tasks, indicating that the frequency is positively linked with the intensity accounting outsourcing activities $(p<0.01)$. The values are significant, but the effect is in the opposite direction than expected. Hence, Hypothesis 1 was not supported. Accordingly, the results show a significant negative coefficient value of -0.203 for asset specificity, suggesting that asset specificity is negatively associated with management accounting outsourcing, thereby confirming $\mathrm{H} 2$ $(\mathrm{p}<0.01)$. Furthermore, as shown in Model 2, the link between opportunism and management accounting outsourcing is generated a negative coefficient value of -0.573 and this is significant $(p<0.01)$. This means that opportunism was highly associated with accounting function outsourcing intensity. Hence, Hypothesis 3 is supported in this study. Additionally, The hypothesis 4 receiving significant postitive coefficient value of 0.451 , which posits a positive relationship between trust in the external accountant and outsourcing intensity $(\mathrm{p}<0.01)$. Hence, strong support was found for Hypothesis 4, thereby confirming H4. Finally, It also indicates that the outsourcing intensity is significantly positively associated with the degree of competition value of 0.109 , which supports for Hypothesis $5(\mathrm{p}<0.05)$, that the competition among SME was associated with outsourcing of accounting functions.

\subsubsection{Testing for Control Variables Effects}

We noted that gender, education, experience, firm size and age of the firm might also have an impact on outsourcing of management accounting functions. Adjusted R2 indicates that $61 \%$ of the variance of "outsourcing intensity" is explained by the Model 2 of Table 4. Consequently, the results suggest that all independent variables (frequency of non-routine tasks, asset specificity, opportunism, trust in accountant and competition) were remained significant at $\mathrm{p}<0.01$ or $\mathrm{p}<0.05$, respectively. 
Table 3. Descriptive statistics and correlation matrix

\begin{tabular}{|c|c|c|c|c|c|c|c|c|c|c|c|c|c|}
\hline Variables & Mean & S.D & 1 & 2 & 3 & 4 & 5 & 6 & 7 & 8 & 9 & 10 & 11 \\
\hline Outsourcing & 3.52 & 1.05 & 1 & & & & & & & & & & \\
\hline Frequency & 3.29 & 1.00 & $-.115^{*}$ & 2 & & & & & & & & & \\
\hline Asset & 4.61 & 1.02 & $-.131 *$ & $-.183 * *$ & 3 & & & & & & & & \\
\hline \multicolumn{14}{|l|}{ Specificity } \\
\hline Opportunism & 4.74 & 0.93 & $-.671 * *$ & $.272 * *$ & -.025 & 4 & & & & & & & \\
\hline Trust in & 4.18 & 0.98 & $.567 * *$ & $-.268 * *$ & $.236^{* *}$ & $-.417 * *$ & 5 & & & & & & \\
\hline \multicolumn{14}{|l|}{ Accountant } \\
\hline Competition & 4.55 & 0.85 & $.268 * *$ & $-.156^{* *}$ & $-.224 * *$ & $-.213 * *$ & .106 & 6 & & & & & \\
\hline Gender & 1.22 & 0.41 & .034 & -.079 & .081 & -.029 & .093 & .032 & 7 & & & & \\
\hline Education & 1.22 & 0.46 & -.033 & -.070 & -.078 & .035 & -.050 & -.033 & .033 & 8 & & & \\
\hline Experience & 1.81 & 1.14 & $.126^{*}$ & .037 & $-.134 *$ & -.073 & .017 & .022 & -.005 & .102 & 9 & & \\
\hline Size & 4.15 & 2.07 & -.125 & .040 & -.021 & .108 & -.075 & .044 & $-.136^{*}$ & -.096 & .001 & 10 & \\
\hline Age & 3.52 & 1.60 & -.020 & -.039 & .053 & .109 & .009 & -.047 & .098 & -.036 & -.006 & -.026 & 11 \\
\hline
\end{tabular}

Note. ** correlation is significant at the 0.01 level (2-tailed); *correlation is significant at the 0.01 level (2-tailed).

Table 4. Result of regression analyses

\begin{tabular}{|c|c|c|}
\hline \multirow{3}{*}{ Variables } & \multicolumn{2}{|c|}{ Outsourcing } \\
\hline & Model 1 & Model 2 \\
\hline & Coefficient (S.E) & Coefficient (S.E) \\
\hline Frequency & $0.123(0.040)^{* * *}$ & $0.125(0.041)^{* * *}$ \\
\hline Asset Specificity & $-0.203(0.040)^{* * *}$ & $-0.195(0.041)^{* * *}$ \\
\hline Opportunism & $-0.573(0.046)^{* * *}$ & $-0.568(0.047)^{* * *}$ \\
\hline Trust in Accountant & $0.451(0.044)^{* * *}$ & $0.444(0.044)^{* * *}$ \\
\hline Competition & $0.109(0.047)^{* *}$ & $0.120(0.049)^{* * *}$ \\
\hline Gender & - & $-0.016(0.094)$ \\
\hline Education & - & $-0.011(0.083)$ \\
\hline Experience & - & $0.047(0.034)$ \\
\hline Size & - & $-0.029(0.019)$ \\
\hline Age & - & $0.031(0.024)$ \\
\hline Constant & $4.386(0.482)$ & $4.264(0.534)$ \\
\hline $\mathrm{R}^{2}$ & .622 & 0.629 \\
\hline Adjusted $\mathrm{R}^{2}$ & .615 & 0.616 \\
\hline F-value & 97.020 & 48.751 \\
\hline DF-Model & 5 & 10 \\
\hline
\end{tabular}

Note. $\mathrm{n}=302$. Unstandardized coefficients reported. Numbers in parentheses are Standard Errors (S.E).

*** Significant at $1 \%$ level; ** Significant at $5 \%$ level; * Significant at $10 \%$ level 0.01 or 0.05 OR 0.10 .

\section{Discussion and Conclusion}

This study examines the important factors affecting the firm's outsourcing decision from TCE and RBV prospective in the Pakistani context. The need for this was the fact that similar studies have been conducted in different setting, i.e. Developed countries, Europe, America, Australia and one study in Iran, but no data were available for Pakistani SMEs. This paper has found support for three TCE predictions and one RBV prediction.

Our empirical analysis has provided no support for TCE's frequency prediction, which indicates that the higher the level of frequency of non-routine accounting functions, the less likely to be performed inside the firm. In other words, SMEs are not capable to generate economies of scale for the non-routine management accounting practices that are recurrent and sizeable, in order that they are less likely to provide such accounting functions inside the firm. Hence, our finding contradict with previous study (Everaert et al., 2010; Kamyabi \& Devi, 2011e; Spekle' et al., 2007; Widener \& Selto 1999; Williamson, 1985) which indicated frequency was statistically and negatively related to outsourcing of routine and non-routine accounting tasks.

The research results found that the asset specificity has a significant negative relationship with accounting 
outsourcing choice. This finding was supported by earlier studies of (Kamyabi \& Devi, 2011e; Steven et al., 2009; Alvarez-Suescun, 2010; Everaert et al., 2010; Spekle' et al., 2007; Widener \& Selto 1999) which indicated asset specificity was statistically and negatively related to outsourcing of management accounting functions. In other words, when the management accounting activities have high intensity of asset specificity, the contractual negotiations more contentious and the search for external accountants will be longer (Kamyabi \& Devi, 2011e).

The finding has provided strong support for TCE's opportunism prediction, which indicates higher the level of perceived opportunism of external accountant, the less likely for SMEs owners/managers prefer outsourcing of accounting functions. Therefore, this finding appears to be in line with a prior research conducted. (Steven et al., 2009; Wang, 2002). Opportunistic behavior of an accountant has a big influence on Pakistani SMEs decisions toward accounting outsourcing and complementary factor in the governance of exchange relationships. Therefore, most of the larger SMEs internalized their accounting functions due to threat of opportunistic behavior of an external accountant.

Trust in the external accountant was significantly positively linked with the management accounting activities. This result is consistent with the TCE presupposition which argues trust is developed by the relationship between the parties to help minimize opportunism and transaction cost. This was supported in previous studies by (Kamyabi \& Devi, 2011c; Everaert et al., 2010; Verwaal et al., 2008; Kamyabi \& Devi, 2011) that found a positive significant relationship between trust in external services provider and outsourcing of service functions. Therefore, in the context of Pakistan, trust is considered as an important and influential factor in business operation, all the business dealing is based on trust, especially when deciding for external service provider.

The finding has provided support for RBV competition prediction. The results showed that competition has a significant positive association with accounting outsourcing. This finding was supported by earlier studies of (Kamyabi \& Devi, 2011c; Kamyabi \& Devi, 2011) and contradictory with a prior study conducted in Norway by Gooderham et al. (2004) and in Australia by Lamminmaki (2008) which indicated that business advice of external accountant was not related to the degree of competition. We believe that the reasons could be twofold: first, the earlier search was carried out in a more developed countries, while this study was conducted within developing countries such as in Iran by Kamyabi \& Devi (2011) and this current research in Pakistan, thus underlining the importance of RBV theory and its applicability in a new context of the economy; Second, the sample of this study included the small and medium enterprises while previous research (Gooderham et al., 2004.) focused on micro and small enterprises (20 employees), hence suggesting an impact of size on the need for outsourcing services. This finding indicates that the owners / managers are willing to use external accountants when the company has many different market segments, customers and products. Therefore, SMEs outsource their management accounting functions in order to be more competitive and efficient in the market.

Finally, it is remarkable that control variables (gender, education, experience, firm size and firm age) were not linked with management accounting functions outsourcing decision.

\subsection{Research and Practical Implications}

This resarch showing some practical implications. Firstly, this research look at a high intensity factor affecting outsourcing accounting functions and this study confirms a previous study (Everaert et al., 2010; Kamyabi \& Devi, 2011), and extends by two independent variables, including frequency of non-routine tasks and opportunism as factors making the decision of a company to outsource management accounting functions, thereby this study contributes to the emerging econmices literature. Secondly, this is the first study conducted to analyze the services of external accountants in the Pakistani prospective and finding revealed that SMEs outsource management accounting services to an external accountants. Thirdly, the greater part of SMEs in emerging economies are facing in-house resource gaps and normally communicate to external accountants to fill up these gaps. Obviously, the professional accountants are able with unique skills to meet the requirements of SMEs, but it is notable that services provided by external accountant to SMEs are only fit for specific pursposes (e.g., high quality and relevant). Finally, if accounting professionals wish to broaden their services, particularly for SMEs in the manufacturing sector, this research emphasize that they must shift to knowledge-based occupations and strengthen their multidisciplinary expertise. Whether or not external accountants may be capable to realize this change is questionable. This implies accounting expert should explore opportunities to improve the services provided by professional accountants.

\subsection{Limitations and Suggestions for Future Research}

The current study has some limitations that can be addressed in future research. Firstly, it only focuses on SMEs involved in the manufacturing sector. Future research should include services sector as well. Secondly, for this research, we use quantitative methods of research, it might be an interesting future researcher can use qualitative 
methods to understand the entire scenario of SMEs accounting outsourcing practices in Pakistan. Thirdly, The data collection and sample size were restricted to 302 SMEs only. There may be a chance of biased responses since data was collected during daytime only. This bias may be reflecting the fact that working SMEs owners/managers/CFO are less available during the official working hours and may have different opinions regarding accounting outsourcing practices. Finally, theories of TCE and RBV showed that SMEs get advantage by outsourcing of management accounting functions, however, we have not been able to look at its effect on business performance. Thus, it is recommended that future research should investigate in more detail the effect of outsourcing accounting functions on firm performance.

\section{References}

Ale-Ebrahim, N., Ahmed, S., \& Taha, Z. (2010). Critical factors for new product developments in SMEs virtual team. African Journal of Business Management, 4(11), 2247-2257.

Audet, J., \& St-Jean, E. (2007). Factors affecting the use of public support services by SME owners: evidence from a periphery region of Canada. Journal of Developmental Entrepreneurship, 12(2), 165-180. http://dx.doi.org/10.1142/S1084946707000629

Badshah, I., Frode M., Konstantin T. (2013). Accounting from a Religious Perspective: A Case of the Central Government Accounting in Islamic Republic of Pakistan. Asian Economic and Financial Review, 3(2), 243-258.

Barney. (1991). Firm Resources and Sustained Competitive Advantage. Journal of Management, 17(1), 99-120. http://dx.doi.org/10.1177/014920639101700108

Bennett, R., \& Robson, P. (1999). The use of external business advice by SMEs in Britain. Entrepreneurship and Regional Development, 11(2), 155-180. http://dx.doi.org/10.1080/089856299283245

Bennett, R., \& Robson, P. (2003). Changing use of external business advice and government support by SMEs in the 1990s. Regional Studies, 37(8), 795-811. http://dx.doi.org/10.1080/0034340032000128721

Brandau, M., \& Hoffjan, A. H. (2010). Exploring the involvement of management accounting in strategic decisions and control: The case of offshoring. J. Accounting and Organizational Change, 6(1), 72-95. http://dx.doi.org/10.1108/18325911011025704

Carey, P., Subramaniam, N., \& Ching, K. C. W. (2006). Internal audit outsourcing in Australia. Accounting and Finance, 46, 11-30. http://dx.doi.org/10.1111/j.1467-629X.2006.00159.x

Chang, Y. C., Chen, Y. C., \& Kuo, T. K. (2009). Strategic technology sourcing in corporate ventures A study of Taiwanese pharmaceutical firms. International Journal of Entrepreneurial Behaviour \& Research, 15(5), 497-517. http://dx.doi.org/10.1108/13552550910983040

Delmotte, J., \& Sels, L. (2008). HR outsourcing: threat or opportunity? Personnel Review, 37(5), 543-563. http://dx.doi.org/10.1108/00483480810891673

Devi, S. S., \& Samujh, R. H. (2010). Accountants as Providers of Support and Advice to SMEs in Malaysia (Research report No. 118). ACCA, London.

Dyer, L. M., \& Ross, C. A. (2008). Seeking advice in a dynamic and complex business environment: Impact on the success of small firms. Journal of Developmental Entrepreneurship, 13(2), 133-149. http://dx.doi.org/10.1142/S1084946708000892

Espino-Rodríguez, T. F., Lai, P. C., \& Baum, T. (2008). Asset specificity in make or buy decisions for service operations: An empirical application in the Scottish hotel sector. International J. Service Industry Manage, 19(1): 111-133. http://dx.doi.org/10.1108/09564230810855734

Espino-Rodríguez, T. F., \& Padrón-Robaina, V. (2004). Outsourcing and its impact on operational objectives and performance: a study of hotels in the Canary Islands. Hospitality Management, 23, 287-306. http://dx.doi.org/10.1016/j.ijhm.2003.11.004

Everaert, P., Sarens, G., \& Rommel, J. (2007). Sourcing strategy of Belgian SMEs: empirical evidence for the accounting services. Production Planning \& Control, 18(8), 716-725. http://dx.doi.org/10.1016/j.ijhm.2003.11.004

Everaert, P., Sarens, G., \& Rommel, J. (2010). Using Transaction Cost Economics to explain outsourcing of accounting. Small Bus Econ, 35(1), 93-112. http://dx.doi.org/10.1007/s11187-008-9149-3

Farooq, O. (2013). Pakistan Economic Survey 2012-13 Report. Chapter Two Agriculture, Ministry of Finance, 
Pakistan.

Gooderham, P. N., Tobiassen, A., Doving, E., \& Nordhaug, O. (2004). Accountants as sources of business advice for small firms. International Small Business Journal, 22(1), 5-22. http://dx.doi.org/10.1177/0266242604039478

Gottschalk, P., \& Solli-Seether, H. (2006). Maturity model for IT outsourcing relationships. Industrial Management \& Data Systems, 106(2), 200-212. http://dx.doi.org/10.1108/02635570610649853

Greenberg, P. S., Greenberg, R. H., \& Antonucci, Y. L. (2008). The role of trust in the governance of business process outsourcing relationships A transaction cost economics approach. Business Process Management J., 14(5), 593-608. http://dx.doi.org/10.1108/14637150810903011

Hawkins, T., Knipper, M. G., \& Strutton, N. (2009). Opportunism in Buyer-Supplier Relations: New Insights from Quantitative Synthesis. Journal of Marketing Channels, 16, 43-75. http://dx.doi.org/10.1080/10466690802147961

Institute of Chartered Accountants of Pakistan. (2007). Review of Practical Implementation Issues of International Financial Reporting Standards-Case study of Pakistan. Retrieved January 26, 2014, from http:/www.adoptifrs.org/uploads/Pakistan/Review\%20of\%20Pracical\%20Implementation\%20Issues\%20of $\%$ 20Internatioal\%20Fin.pdf

Ismail, N. A., \& King, M. (2005). Firm performance and AIS alignment in Malaysian SMEs. International Journal of Accounting Information Systems, 6, 241-259. http://dx.doi.org/10.1016/j.accinf.2005.09.001

Ismail, N. A., \& Zin, R. M. (2009). Usage of Accounfing Informafion among Malaysian Bumipufra Small and Medium Non-Manufacfuring Firms. Journal of Enterprise Resource Planning Studies, 1(2), 11-17.

Jap, S. D., \& Anderson, E. (2003). Safeguarding interorganizational performance and continuity under ex post opportunism. Management Science, 49(12), 1684-1701. http://dx.doi.org/10.1287/mnsc.49.12.1684.25112

Jayabalan, J., Raman, M., Dorasamy, M., \& Ching, N. K. C. (2009). Outsourcing of Accounting Functions amongst SME Companies in Malaysia: An Exploratory Study. Accountancy Business and the Public Interest, 8(2), 96-114.

Jiang, B., \& Qureshi, A. (2006). Research on outsourcing results: current literature and figure opportunities. Management Decision, 44(1), 44-55. http://dx.doi.org/10.1108/00251740610641454

Jiang, B., Belohlav, J. A., \& Young, S. T. (2007). Outsourcing impact on manufacturing firms' value: Evidence from Japan. Journal of Operations Management, 25, 885-900. http://dx.doi.org/10.1016/j.jom.2006.12.002

Joshi, A. W., \& Stump, R. L. (1999). Determinants of commitment and opportunism: Integrating and extending insights from transaction cost analysis and relational exchange theory. Canadian Journal of Administrative Sciences, 16, 334-352. http://dx.doi.org/10.1111/j.1936-4490.1999.tb00693.x

Kamyabi, Y., \& Devi, S. (2011a). An Empirical Investigation of Accounting Outsourcing in Iranian Investigation of Accounting Outsourcing in Iranian Based Views. International J. Business and Management, 6(3), 81-94.

Kamyabi, Y., \& Devi, S. (2011c). Use of Professional Accountants' Advisory Services and its Impact on SME Performance in an Emerging Economy: A Resource-based View. J. Management and Sustainability, 1(1), 43-55.

Kamyabi, Y., \& Devi, S. (2011). The Impact of Accounting Outsourcing on Iranian SME Performance: Transaction Cost Economics and Resource-Based Perspectives. World Applied Sciences Journal, 15(2), 244-252.

Kamyabi, Y., \& Devi, S. (2011d). Using Transaction Cost Economics and Resource-Based views in Management Accounting Outsourcing: An empirical study of Iranian SMEs. Middle East Journal of Scientific Research, 10(1), 87-98.

Kamyabi, Y., \& Devi, S. (2011e). Outsourcing of accounting functions in the context of SMEs in emerging economies: Transaction cost economics perspective. Australian Journal of Basic and Applied Sciences, 5(11), 1696-1703.

Khalique, M., Hassan A. M. I., Shaari, J. A. N. (2011). Challenges for Pakistani SMEs in a Knowledge-Based Economy. Indus Journal of Management \& Social Sciences, 5(2), 74-80.

Klein, P. G. (2005). The make-or-buy decision: Lessons from empirical studies. In C. Me'nard \& M. Shirley 
(Eds.), Handbook of institutional economics (pp. 435-464). New York: Springer. http://dx.doi.org/10.1007/0-387-25092-1_18

Kotabe, M., \& Mol, M. J. (2009). Outsourcing and financial performance: A negative curvilinear effect. $J$. Purchasing and Supply Management, 15, 205-213. http://dx.doi.org/10.1016/j.pursup.2009.04.001

Kwon, I. G., \& Suh, T. (2005). Trust, commitment and relationships in supply chain management: A path analysis. Supply Chain Management, 10(1), 26. http://dx.doi.org/10.1108/13598540510578351

Lai, F., Tian, Y., \& Hou, B. (2012). Relational governance and opportunism in logistics outsourcing relationships: empirical evidence from China. International Journal of Production Research, 50(9), 2501-2514. http://dx.doi.org/10.1080/00207543.2011.581011

Lamminmaki, D. (2005). Why do hotels outsource? An investigation using asset specificity. International Journal of Contemporary Hospitality Management, 17(6), 516-528. http://dx.doi.org/10.1108/09596110510612158

Lamminmaki, D. (2007). Outsourcing in Australian Hotels: A transaction cost economics perspective. $J$. Hospitality and Tourism Res., 31, 73-110. http://dx.doi.org/10.1177/1096348006296714

Lamminmaki, D. (2008). Accounting and the management of outsourcing: An empirical study in the hotel industry. Management Accounting Res., 19, 163-181. http://dx.doi.org/10.1016/j.mar.2008.02.002

Lee, D. J. (1998). Developing international strategic alliances between exporters and importers: The case of Australian exporters. International Journal in Marketing, 15, 335-348. http://dx.doi.org/10.1016/S0167-8116(98)00010-X

Lee, J. N., Huynh, M. Q., \& Hirschheim, R. (2008). An integrative model of trust on IT outsourcing: Examining a bilateral perspective. Inf. Syst. Front, 10, 145-163. http://dx.doi.org/10.1007/s10796-008-9066-7

Mahmoodzadeh, E., Jalalinia, S., \& Yazdi, F. N. (2009). A business process outsourcing framework based on business process management and knowledge management. Business Process Management Journal, 15(6), 845-864. http://dx.doi.org/10.1108/14637150911003748

Martin, C. (2005). Accountancy practices and the provision of ownership succession advice (NO. 85). The Association of Chartered Certified Accountants.

Mashayekhi, B., \& Mashayekh, S. (2008). Development of accounting in Iran. The International Journal of Accounting, 43, 66-86. http://dx.doi.org/10.1016/j.intacc.2008.01.004

Mclvor, R. (2009). How the transaction cost and resource-based theories of the firm inform outsourcing evaluation. Journal of Operations Management, 27, 45-63. http://dx.doi.org/10.1016/j.jom.2008.03.004

McNally, R. C., \& Griffin, A. (2004). Firm and individual choice drivers in make-or-buy decisions: a diminishing role for transaction cost economics? The Journal of Supply Chain Management, 40(1), 4-17. http://dx.doi.org/10.1111/j.1745-493X.2004.tb00252.x

Mole, K., Hart, M., Roper, S., \& Saal, D. (2008). Differential gains from Business Link support and advice: a treatment effects approach. Environment and Planning C: Government and Policy advance online publication.

Murray, J. (2001). Strategic alliance-based global sourcing strategy for competitive advantage: A conceptual frame work and research propositions. Journal of International Marketing, 9(4), 30-58. http://dx.doi.org/10.1509/jimk.9.4.30.19938

Murray, J., \& Kotabe, M. (1999). Sourcing strategies of U.S. service companies: A modified transaction-cost $\begin{array}{lllll}\text { analysis. Strategic } & \text { Management }\end{array}$ http://dx.doi.org/10.1002/(SICI)1097-0266(199909)20:9<791::AID-SMJ49>3.0.CO;2-U

Nandan, R. (2010). Management accounting needs of SMEs and the role of professional accountants: A renewed research agenda. Journal of Applied Management Accounting Research (JAMAR), 8(1), 65-78.

Nicholson, B., Jones J., \& Espenlaub, S. (2006). Transaction costs and control of outsourced accounting: Case evidence from India. Management Accounting Res., 17, 238-258. http://dx.doi.org/10.1016/j.mar.2006.05.002

Park, D., \& Krishnan, H. (2001). Supplier selection practices among small firms in the United States: Testing three models. Journal of small Business Management, 39(3), 259-271. http://dx.doi.org/10.1111/0447-2778.00023 
Poppo, L., \& Zenger, T. (1998). Testing alterative theories of the firm: transaction cost, knowledge-based, and measurement explanations for make-or-buy decisions in information services. Strategic Management Journal, 19(9),

853-877. http://dx.doi.org/10.1002/(SICI)1097-0266(199809)19:9<853::AID-SMJ977>3.0.CO;2-B

Rashid, A. R., Amin, F., \& Farooqui, A. (2012). International financial reporting standards (ifrs) and its influence on pakistan. Journal of Applied Finance \& Banking, 2(2), 1-13.

Reeves, K. A., Caliskan, F., \& Ozcan, O. (2010). Outsourcing distribution and logistics services within the automotive supplier industry. Transportation Research Part E, 46, 459-468. http://dx.doi.org/10.1016/j.tre.2009.10.001

Saeed, K. A. (1993). A global perspective of accounting education and certification process: A chapter with focus on Pakistan. New York: Pergamon Press.

Spekle, R. F., Van Elten, H. J., \& Kmis, A. M. (2007). Sourcing of internal auditing: An empirical study. Management Accounting Research, 18(1), 102-124. http://dx.doi.org/10.1016/j.mar.2006.10.001

Steven, S. L., Yin-yee, W., \& Weiping, L. (2009). Asset specificity roles in interfirm cooperation: Reducing opportunistic behavior or increasing cooperative behavior? Journal of Business Research, 62(11).

Tian, Y., Lai, F., \& Daniel, F. (2008). An examination of the nature of trust in logistics outsourcing relationship: Empirical evidence from China.

Verwaal, E., Verdú, A. J., \& Recter, A. (2008). Transaction costs and organisational learning in strategic outsourcing relationships. Int. J. Technology Management, 41(1/2), 38-54. http://dx.doi.org/10.1504/IJTM.2008.015983

Wang, E. T. G. (2002). Transaction attributes and software outsourcing success: an empirical investigation of transaction cost theory. Information Systems Journal, 12, 153-181. http://dx.doi.org/10.1046/j.1365-2575.2002.00120.x

Wasti, E. S. (2013). Pakistan Economic Survey 2012-13 Report. Overview of the Economy, Ministry of Finance, Pakistan.

Wathne, K. H., \& Heide, J. B. (2000). Opportunism in interfirm relationships: Forms, outcomes, and solutions. Journal of Marketing, 64, 36-51. http://dx.doi.org/10.1509/jmkg.64.4.36.18070

Watjatrakul, B. (2005). Determinants of IS sourcing decisions: A comparative study of transaction cost theory versus the resource-based view. Journal of Strategic Information Systems, 14(4), 389-415. http://dx.doi.org/10.1016/j.jsis.2005.05.001

Widener, S., \& Selto, F. (1999). Management control systems and boundaries of the firm: Why do firms outsource internal auditing activities? Journal of Management Accounting Research, 11, 45-73.

Williamson, O. (1985). The economic institutions of capitalism. New York: Free Press.

Worrall, L. (2007). Transforming regional economic performance through business transformation. International J. Management Practice, 2(4), 324-344. http://dx.doi.org/10.1504/IJMP.2007.012749

\section{Copyrights}

Copyright for this article is retained by the author(s), with first publication rights granted to the journal.

This is an open-access article distributed under the terms and conditions of the Creative Commons Attribution license (http://creativecommons.org/licenses/by/3.0/). 